\section{解 説}

\title{
The New Zealand forest model: - A possible solution -
}

\author{
Nicola SPENCE*
}

\section{1.はじめに}

この報告では，ニュージーランドにおける森林の多 様な利用と, 天然林の保護を目的とした森林管理の方 法の概要を述べる。そして，この方法による森林開発 が環境を破壊しない，ひとつのモデルになりうるかを 考えてみる。ニュージーランドの人工林造成は, 環境 を破壊しない開発例として，国連環境開発会議におい て発表されて, 他の国々の代表者にも受け入れられて いる。それゆえに、ニュージーランドで行われている 人工林管理の方法の妥当性を検証することは, 国際的 に人工林問題を討議する場合に重要である。

1992年のリオ国連会議に先立ち、ニュージーランド 代表は，現在行われている人工林管理の方法は環境保 全において成功していること，そして，木材生産が経 済成長に貢献できることを, 経験に基づき説明した。こ こでは, ニュージーランドの人工林管理について, 環 境的な側面と経済的な側面とを述べる。

\section{2.人工林と環境}

人工林はさまざまな面で, ニュージーランドの環境 保全に貢献している。まず，二酸化炭素の吸収源とし て重要な役割を果している。森林局は主だった研究者 による研究委員会を 1992年に設置し，そこで二酸化炭 素の吸収に果たす森林の役割について科学的な検討を 行った $(1)$ 。その検討結果を森林局長ジョン・バレンタ イン博士は次のように発表した。「1989年3月までの一 年間に, ニュージーランドの国土面積の $4 \%$ に相当する 人工林は 360 万 500 万トンの炭素を吸収した。これは, 石油使用によりニュージーランド全体で放出されると 推定される炭素総量の 50 70\%に相当する」。このよう に，人工林はこの国の環境の向上に貢献しているとい える。すなわち，人工林の成長率は大きいので，国内 で放出される炭素量の相当の部分を吸収しているとい える。成長が早いことは炭素の吸収・固定に効果がある が，これに対し，老齢木では成長が止まり，朽ち始め ると炭素を放出し始める。このため, ニュージーラン
ドの老秢天然林は，面積的には少ない人工林よりも炭 素の吸収量が少ない(2)。

人工林率が増えるに従って，環境の保全に貢献でき るであろう。今後, 人工林率が增加した場合は, ニュー ジーランドは安全な二酸化炭素濃度を達成することは 可能であるといわれる (3)。人工林はニュージーランド の正味二酸化炭素放出量に相当する量を吸収するのに, 重要な役割を果していることは明らかである。なお，政 府はリ才会議に先立ち，1990年を基準として，二酸化 炭素放出量の水準を 2000 年までに $20 \%$ 減少させること を約束している。この二酸化炭素の水準を長期的に低 下させるには，石油使用量を減らすことにかかってい るが, 人工林による炭素吸収は長期的な方法が開発さ れるまでの暫定的な方法として，効果的である。1994 年 8 月の気候変動会議において, ニュージーランド代表 は，二酸化炭素の残存量は目標値まで減少したことを 発表している。

次に，人工林は天然林伐採への圧力を減らすことで 環境保護に貢献している。その結果, 人工林は固有種 と天然林の生態系の保護に役立っているといえる。す なわち, ニュージーランドの人工林林業は, 天然林と 野生生物の保護に役立っていることが認められている。

ニュージーランドの森林所有者協会が作成した, 1991 年の森林協定において，林業および環境団体の代 表者は，天然林を保護する役割を人工林に認めたが，こ れは先例のないことである $(4)$ 。この協定では次のよう に述へられている。「外来樹種あるいは在来樹種による 産業としての人工林は, 減少した天然林に代わる半永 久的に持続可能な重要なエネルギー源である」。この協 定に署名した保護団体は，国内的にも国際的にも人工 林は木材を継続的に供給し，原生林を保護する手段と して認め, 推進することを約束した。このニュージー ランド森林協定は，天然林を保護する一方で，持続的 な人工林の管理を推進することにより，林業側と環境 保護団体側の利益が一致するということを世界に示し た例である $(5)$ 。

ニュージーランド政府は原生林を保護する一方で, 人 工林造成を推進する政策を採用している。1993年に施

* 大阪大学法学部 Fac. of Law, Osaka Univ., Osaka 560 
行された改正森林法はこの政策の結果である。この法 律の目的は原生林の継続的な維持管理を推進すること である。天然林からの伐採制限, 輸出規制と継続的な 管理計画によりこの目的を果たそうとしている。なお， この法律は人工林には適用されない。しかし, 天然林 の管理について, 現在問題はある。ニュージーランド の環境団体の保護活動にも関わらず，西海岸の南部地 方では，天然ブナ林が伐採されている。これは森林協 定が結ばれる以前の伐採権に対しては, 協定は適用さ れないからである。政府は 1994 年までは例外として, 天然林伐採を認めている $(6)$ 。

更にニュージーランドの人工林が環境に与える明白 な影響として，ラジアータ松は侵食に弱い急斜面でも 成長するということが挙げられる (7)。それゆえ, 人工 林は斜面を固定し，土地を肥沃にするのに役立ってい る $(8)$ 。ニージーランドでは土地と水と日光さえあれ ば，ラジアータ松は十分に有つからである。

\section{3.人工林亡経済発展}

人工林造成は二ュージーランドの重要産業であり, 将 来的な経済成長の可能性を約束している。人工林は二 ュージーランドの産業的に利用できる国土面積の約 $8 \%$ ，つまり 150 万h hを占めている $(9)$ 。ュュージーラン ドの人工林からの木材産業はふたつの国内総生産の約 5.7\%を占め, 輸出額の $12.7 \%$ (270億 $\mathrm{NZ}$ ドル)を占めて いる $(10) 。 1970$ 年代から 80 年代にかけての植林ブーム のおかげで, この先の 20 年間は輸出用木材量は大幅に 増え，2005年までに木材収益は, 現在の収益の二倍に なると計画されている $(11)$ 。利用可能な木材量が増え ることにより, 付加的価値生産への投資機会, 輸出収 益の比例的な増加の潜在力も増えることになる。たと えば，設備を新しくするために，1 億 2000 万 NZドルを 投資すれば，輸出収益は 11 億 NZドル増えることにな る。すなわち，人工林が増えれば収益は更に増え，木 材収益が増えれば、ニュージーランドの投資機会は更 に増えるといえる。一つの試算では，木材収益は 2010 年までに, ニュージーランドの輸出収益の約 $30 \%$ を占 めるようになると見積もっている(12)。つまり，人工林 からの収益と生産物はニュージーランドの経済成長に とって重要な潜在力となり得る。

人工林は伝統的な「農家林業」, つまり商業的収益を あげるために所有する農地で, 農家が小規模の植林を 行うことにより, 経済成長に更に貢献することができ る。そのために環境的関心と開発的関心が農家林業に 向けられている。人工林は斜面を固定し, 集約農業の ためにやせた土地を元通りにするからである。また農 家林業が重要視されるのは, それが多角経営だからで
ある。つまり，農業的林業と商業的林業を同時に行う ことで，国際市場での第一次生産物価格の不安定性に より生じるダメージを減らすことができるからである。

人工林の経済的側面に関する利益で重要なものの一 つは, リ才国連会議でっくられた生態効率 (ecoefficiency) という概念を使用することである(13)。生態 効率とは企業が最小限の資源で污染を最小限に抑えて, 生産物に最大限の価值を与えるという概念である。先 進国では, 生態効率の高い企業が市場で優遇される傾 向にあることが, 事前の会議での議題となった (14)。生 態効率が経済上, 正当に評価されている限り, 人工林 は環境保護の傾向にある国際市場で優遇され，人工林 からの生産物は地球に優しいと宣伝できる。

\section{4.人工林に付随する問題}

多くの環境学や社会学の研究者は, ラジアータ松の みで構成される人工林の問題点について照念を表明し ている。彼らの懸念の内容および，人工林への批判的 な懸念に対する対応の内容を以下に述べる。著者は, 人 工林に対する批判はあるが，天然林を伐採するよりは 好ましいと考えている。

ラジアータ松の人工林は森林として考えてょいのか ?または，樹木を完全に伐採してしまえば，土鎄が水に より侵食される恐れがあるのに繰り返して生産物を得 られるのか？という疑問を研究者はかなり懸念している (15)。

たしかに, 土壤の侵食は人工林が持っている弱点と してもっとも深刻なものである。しかし，土壌の健全 性, 肥沃性, 生物学的多様性についても多くの優れた 側面が存在する。つまり, 牧草地や農耕地の代わりに 人工林を配置する場合は, 土地の交替使用法として優 れている。また, 土地の深部から表面まで, 養分を循 環させるといった有益な効果もある。しかし，十分に 調査されていないので証明は難しいが，人工林は単一 樹種林なので，土壌に悪影響を与える恐れがある。

一方で，樹木を完全に伐採したり，土地を肥沃にす るための火入れが，土地の生物学的多様性つまりその 土壌に生息している動物相と植物相に悪影響を与えて いるという学者もいる。ラジアータ松は天然林よりも 成長が早いので, 土壌に含まれる有機物を先に使い切 ってしまうことや無機化学肥料に依存してしまうこと は問題である $(16)$ 。つまり，いつまでも分解されない無 機化学肥料を使用できるのか?川や湖の富栄養化は大丈 夫なのか?土袞の動物相・植物相および自然的特性への 影響はどうなるのか? 製造・流通・応用に利用されるエ ネルギーがなくなった場合は考慮されているのか?とい う問題である。 
人工林はニュージーランドの二酸化炭素を効果的に 吸収している，という林業および政府の主張を，疑問 視する科学者もいる。人工林は牧草地よりも環境保全 に役立つが，林業界は二酸化炭素吸収体としての人工 林を必要としているのではな区，人工林からの森林生 産物を必要としているのであって，それにより発生す る二酸化炭素のことは考慮にいれていない。成長中の 人工林は二酸化炭素吸収体であると認めても, 植林す る時や，土地を肥沃にするために施肥する時，また木 材を加工する時に石油燃料を使用して, 結局二酸化炭 素を放出する。木材を加工してしまうと，木材と合板 しか二酸化炭素を貯蔵できないとした研究もある。二 ュージーランドで伐採される全木材の 5 分の 1 が住宅用 の木材のように中期的な二酸化炭素貯蔵で終わってし まい,これでさえ家がこわされてしまえば短期の貯蔵 しかできない。更に昆虫による食害や腐敗・燃焼で二酸 化炭素を排出する。それゆえ，耐久性のある木材は，松 のようにあまり耐久性の小さい木にくらべると，長く 二酸化炭素をためることができる。したがって二酸化 炭素を長期にわたって貯蔵することで得られる利益で, 木材の防腐処理にかかるコストを賄うことができる。

ラジアータ松の土壌中の貯水量は, 天然林よりも少 ないが，牧草地よりは多いことが研究により証明され ている。天然林の林床では水が均一に分布されている。 眝水量は少ないがラジアータ林の場合でも水が均一に 分布されている。木を完全に伐採してしまうと, 全く 伐採していない，または部分的に伐採している地域に くらべて, 林床の雨水の吸収率が低くなるので, 洪水 が增える。

森林は斜面と土袞を安定させる機能を持っている。 そのため, 天然林から人工林に切り替える時, 前生木 の根が土袞を支える力を失い，植林木の根が十分に発 達していない 2 年から 8 年の間に多くの問題が生じる。 地滑りによる岩屑や堆積物は川の流れや水質に 20 年以 上にわたり影響を与え続ける。従って, 侵食されつつ ある斜面では，短いローテーションで行う皆伐をさけ て, 不断に地表を植物で覆っている必要があると考え られる。そのために，さまざまな樹種を混ぜた人工林 を作ったり，ヘリコプターで伐採したり，より伐期の 長い樹種を植えるといった方法が選択できる。

単一樹種の人工林の生物多様性は当然内的にも外的 にも天然林より少ない。内的多様性が少ないとは，ほ とんど樹冠や地中の動物相が存在せず，種の中の遺伝 的多様性が低く, 他の種との相互作用がほとんどなく, 生息地が限定され, 地形の多様性もほとんどないこと を意味する。外的多様性とは, 自生のラジアー夕松の 侵入も含む近隣の生態系に人工林が与えた影響や, 小 規模の植林を行った際に，その地域の動物相および植
物相の自然生息地を分断したり移転させることを言う。

\section{注勫及び引用文献}

(1) この委員会は森林の調査研究部門と産業政策部門 を代表する 8 人の学者で構成された。Ministry of Forestry's Policy Division"Pine Helps Combat Greenhouse Effect Feburuary, 1992, 4.

(2) 天然林は国土の約 $25 \%$ を占めるのに対し，人工林 は $4.6 \%$ であ。

(3)このことは先に述べた，バレンタイン博士の発表 にあるとおりである。森林統計書によると, 植林 されたラジアータ松の面積は $6,500 \mathrm{ha}$ である。

(4) 所有者協会は全人工林の約 $90 \%$ を所有するか管理 している。この協定は人工林造成に適している地 域を設定し，天然林保存の価值を認めている。従 って天然林のある地域では，それを保存しつつ開 発すべきだとしている。この協定の核心は，森林 所有者協会員は，人工林を新たに造成する場合に 次の地域に該当すところは保護することを保証し たことである。

a) 樹高に関わらず原生林が優勢種である 5ha以上の 地域

b) 平均樹高 $6 \mathrm{~m}$ 以上の樹冠を持ち, 野生生物のいる 1 5ha 程度の地域

c) 野生生物の保護のため特に必要な地域

d) 自然保護のため特に必要な地域

K.Smith, "The Forest Accord Two Years On", New Zealand Forest and Bird Society Magazine, August.1993.

(5)この協定は他の国においても実現できる可能性が ある。また, 二ュージーランドの林業企業と保護 団体との間の協定によって生じる共通利益で, 国 際的に推進できる例であることも認めている。も っとも, ニュージーランド森林協定は, 人口が少 なく，国内の木材需要が比較的少なく，人工林を 造成するに十分な土地があるというニュージーラ ンド特有の立地条件の結果であることに留意しな ければならない。しかし，この協定は，森林が持 続的に発展すれば，環境面と経済的な面での両方 の利益がどのように調和するかを示した例である。

(6) ウェリントン熱帯雨林活動団体 1993 年 5 月.

(7) McKelvey, P., "The Development of the Concept of Steepland Protection Forestry in New Zealand", May 1992, New Zealand Forestry 20.

(8) 人工林から利益を得る場合，そこにすでに生えて いる前生木からの利益はあきらめなくてはならな い。しかしながら，人工林に植え替える間でも，斜 
面の安定性を得ることができる。木が取り除かれ ても, 根の組織がち中に残るので, 若木の根が十 分に育つまでの間，それが斜面を固定する。しか も低木林の場合よりも地面が乾燥するので, 斜面 の安定性は增す。

(9) Ministry of Forestry, "Investment Opportunities in New Zealand Forest Industry, 1992, 14.

(10) Ministry of Forestry, Statistical Summary, 30 June 1993 ニュージーランドの林業に現在 25,000 人以上 が従事している。Forestry Facts and Figures 1993: by the NZFOA in co-operation with the Ministry of Forestry.

(11) Ministry for the Environment and Ministry of Foreign Affairs and Trade, New Zealand's National Report to the United Nations Conference on Environment and Development-Forging the Links, 1991.

(12) Ministry for the Environment and Ministry of Foreign Affairs and Trade, New Zealand's National Report to the United Nations Conference on Environment and Development-Forging the Links, 1991.

(13) S. Schmidheiny with the Business Council for Sustainable Development, Changing Course-A Global
Business Perspective on Development and the Environment, 1992.

(14)この一貫した傾向は, たとえば, 消費者が環境保全 に役立つ製品を求める, またはマスメディアが企業 活動を監視し，銀行が污染防止を企業に働きかける ということで支えられている。

(15)ここで使われている記事は, Greenpeace Auckland の "Environmental Impacts of Plantation Forestry in New Zealand”を含む。この記事は熱帯雨林活動連 合の Grant Rosomann が執筆し, ”Roots of Concern and Forestry in New Zealand”という題で Eco誌に掲 載された。その他の資料としてはJ.Pelisek 教授に よる "Conifer Plantation and Soil Deterioration" 1975 年 11 月 The Ecologist 誌 9 および The New Zealand Forest and Bird Society 南中部支社による "Draft Guidelines for Plantation”, Forestry 1991 年を挙げ る。

(16) Green Forest, "Environmental Impacts of Plantation Forestry in New Zealand", Greenpeace Auckland, 1993.

(1996 年 10 月 3 日 受理) 